\title{
Nitrogen Fertilization to Maximize Carrot Yield and Quality on a Sandy Soil
}

\author{
George J. Hochmuth ${ }^{1}$, Jeffrey K. Brecht ${ }^{1}$, and Mark J. Bassett ${ }^{\mathbf{1}}$ \\ Horticultural Sciences Department, University of Florida, Gainesville, \\ FL 32611-0690
}

Additional index words. Daucus carota, plant nutrition, plant tissue analyses, carotene, sugar, nutrient uptake

\begin{abstract}
Nitrogen is required for successful carrot production on sandy soils of the southeastern United States, yet carrot growers often apply $N$ in amounts exceeding university recommendations. Excessive fertilization is practiced to compensate for losses of $\mathbf{N}$ from leaching and because some growers believe that high rates of fertilization improve vegetable quality. Carrots (Daucus carota L.) $_{\text {. }}$ were grown in three plantings during Winter 1994-95 in Gainesville, Fla., to test the effects of N fertilization on yield and quality. Yield increased with $\mathbf{N}$ fertilization but the effect of $\mathbf{N}$ rate depended on planting date; $150 \mathrm{~kg} \cdot \mathrm{ha}^{-1} \mathrm{~N}$ maximized yield for November and December plantings but 180 $\mathbf{k g} \cdot \mathrm{ha}^{-1} \mathrm{~N}$ was sufficient for the January planting. Concentration of total alcohol-soluble sugar was maximized at $45 \mathrm{mg} \cdot \mathrm{g}^{-1}$ fresh root with $140 \mathrm{~kg} \cdot \mathrm{ha}^{-1} \mathrm{~N}$ for 'Choctaw' carrots, whereas sugar concentration of 'Scarlet Nantes' roots was not affected by $\mathbf{N}$ fertilization. Carrot root carotenoid concentration was maximized at $55 \mathrm{mg} \cdot \mathrm{kg}^{-1}$ fresh root tissue with $160 \mathrm{~kg} \cdot \mathrm{ha}^{-1} \mathrm{~N}$. Generally, those $\mathrm{N}$ fertilization rates that maximized carrot root yield also maximized carrot quality as determined by sugar and carotenoid concentrations.
\end{abstract}

Carrot is an important vegetable crop in Florida, with 2900 ha planted during the 199596 season (Florida Agricultural Statistical Services, 1997). Most of these carrots were grown on organic soils in central and southern Florida. These Histosol-based production areas have recently come under scrutiny as a potential source of nutrients contributing to the eutrophication of Lake Apopka in central Florida (Conrow, 1989; Crnko et al., 1993). Carrot growers have begun to search for alternative production areas in case farming on the Histosols is increasingly regulated or prohibited in the future. One option would be to move the carrot production to areas with sufficiently long growing seasons and sandy soils, which are especially plentiful in central and northern Florida.

Sandy soils are well suited for carrot production (Boswell, 1963) and are used for this purpose in many states. Research on carrot production on sandy soils was conducted in the early 1960s in Florida (Forbes and Scudder, 1963). However, the organic soils were preferred by commercial growers because of their ease of tillage and the use of fallow flooding to reduce pest problems (Moore, 1949; Strandberg, 1984).

One of the early problems with carrot production on sandy soils in Florida was fertilization. Yields of 'Chantenay' and 'Imperator'

\footnotetext{
Received for publication 11 June 1998. Accepted for publication 19 Oct. 1998. Florida Agricultural Experiment Station Journal Series R-06388. The cost of publishing this paper was defrayed in part by the payment of page charges. Under postal regulations, this paper therefore must be hereby marked advertisement solely to indicate this fact. ${ }^{1}$ Professor.
}

carrots were greatest with $220 \mathrm{~kg} \cdot \mathrm{ha}^{-1} \mathrm{~N}$ (Forbes and Westgate, 1963), and were similar with most $\mathrm{N}$ sources (Forbes, 1966). In Oregon, $\mathrm{N}$ fertilization to $110 \mathrm{~kg} \cdot \mathrm{ha}^{-1}$ increased carrot yield on a silt loam soil in one season but had no effect in another (Hemphill and Jackson, 1982). In Texas, on a sandy loam soil, yields were maximized with $110 \mathrm{~kg} \cdot \mathrm{ha}^{-1} \mathrm{~N}$ (Hipp, 1978). Fertilization of loamy sand soil with 50 to $80 \mathrm{~kg} \cdot \mathrm{ha}^{-1} \mathrm{~N}$ in one study and 50 to 150 $\mathrm{kg} \cdot \mathrm{ha}^{-1}$ in a second resulted in similar yields in Canada (Sanderson and Ivany, 1997).

Results of these studies revealed that $\mathrm{N}$ requirements on sandy soils were as high as $200 \mathrm{~kg} \cdot \mathrm{ha}^{-1}$, but as low as $50 \mathrm{~kg} \cdot \mathrm{ha}^{-1}$ on sandy loams. Researchers focused on carrot yield responses to $\mathrm{N}$ fertilization but seldom evaluated carrot quality characteristics, such as sugar or carotenoid concentrations. Carotenoid content is related to vitamin A content, and flavor components are influenced by genetic and environmental factors (Rosenfeld et al., 1998; Simon et al., 1980, 1982; Simon and Peterson, 1979).

Nitrogen fertilization may affect vegetable quality (Locascio et al., 1984; Mozafar, 1993). High $\mathrm{N}$ fertilization rates reduced dry-matter content and sucrose concentrations in sugar beet (Follett, 1991). Increasing $\mathrm{N}$ fertilization from 170 to $310 \mathrm{~kg} \cdot \mathrm{ha}^{-1} \mathrm{~N}$ enhanced dimethyl sulfide (compound responsible for the aroma of cooked sweet corn) content irrespective of influence on yield (Wong et al., 1995).

Greater fertilization rates of $\mathrm{N}, \mathrm{P}$, and $\mathrm{K}$ led to reduced sugar concentration of carrots in experiments in Finland (Evers, 1989c). Carotene concentration of carrots was increased by band placement of $\mathrm{P}$ and $\mathrm{K}$ fertilizers, but was not improved by increasing $\mathrm{N}$ from 80 to 150 $\mathrm{kg} \cdot \mathrm{ha}^{-1}$ (Evers, 1989b). Increasing $\mathrm{N}$ rates were associated with increasing carotene concentrations in one study (Freeman and Harris, 1951), but in another, the reverse relationship was found (Southards and Miller, 1962).

A review by Mozafar (1993) summarized the effects of $\mathrm{N}$ fertilization on vitamin content of plants, including carrot. Fertilization of vegetables with $\mathrm{N}$ resulted in positive, negative, or no effect on concentrations of several vitamins and the effect was crop-dependent. Nitrogen fertilization studies should, therefore, include evaluation of $\mathrm{N}$ effects on chemical as well as physical quality factors. This study was conducted to evaluate carrot yield and root quality (as determined by concentrations of alcohol-soluble sugar and total carotenoids) responses to $\mathrm{N}$ fertilization on a sandy soil in three plantings made in the winter growing season of 1994-95 in north central Florida.

\section{Materials and Methods}

Research was carried out at the Horticultural Research Unit of the Univ. of Florida in Gainesville during Winter 1994-95 in a field that had been fallow (no cover crop) for the previous 6 months. The soil, an Arredondo fine sand (loamy, siliceous, Hyperthermic Grossarenic Paleudults), was moldboardplowed to a depth of $20 \mathrm{~cm}$ and disked in early Nov. 1994. Prefertilization soil samples were taken with a soil probe from the top $15 \mathrm{~cm}$ of soil. Soil was dried, sieved, and analyzed for $\mathrm{P}$ (medium), $\mathrm{K}$ (low), $\mathrm{Ca}$ (medium), $\mathrm{Mg}$ (medium), $\mathrm{Cu}$ (high), $\mathrm{Mn}$ (low), and $\mathrm{Zn}$ (low) with Mehlich-1 procedures (Hanlon et al., 1994; Mehlich, 1953). Lime requirement (2 th ha' was determined with the Adams-Evans test (Adams and Evans, 1962; Hanlon et al., 1990).

Soil was lifted into raised prebeds with single-disc hillers preceded by a subsoiler shank $(50 \mathrm{~cm}$ deep). Plots (experimental units) were $6 \mathrm{~m}$ in length with a 5-m nonplanted and nonfertilized area between the end of one plot and the beginning of the next. Preplant fertilizer mixtures were sprinkled on the surface of the prebeds. Fertilizer materials and application rates were triple superphosphate $\left(30 \mathrm{~kg} \cdot \mathrm{ha}^{-1}\right.$ $\mathrm{P})$, manganese sulfate $\left(1 \mathrm{~kg} \cdot \mathrm{ha}^{-1} \mathrm{Mn}\right)$, and zinc sulfate $\left(1 \mathrm{~kg} \cdot \mathrm{ha}^{-1} \mathrm{Zn}\right)$. Ammonium nitrate and potassium nitrate were used to supply a uniform amount of $\mathrm{N}$ and $\mathrm{K}$ to the soil in each plot except for plots not receiving N. Potassium chloride alone was applied to the soil for the zero- $\mathrm{N}$ treatments. Totals of $\mathrm{N}$ and $\mathrm{K}$ applied were $20 \mathrm{~kg} \cdot \mathrm{ha}^{-1}$ each.

Following preplant fertilizer application, the soil in the prebeds was rototilled and pressed into firm beds $15 \mathrm{~cm}$ in height and $60 \mathrm{~cm}$ wide across the top surface. Beds were spaced $1.2 \mathrm{~m}$ apart center-to-center.

Nitrogen was applied at rates from 0 to 220 $\mathrm{kg} \cdot \mathrm{ha}^{-1}$ in $55-\mathrm{kg}$ increments. Factorially arranged with $\mathrm{N}$ rate were carrot cultivar (either 'Scarlet Nantes' or 'Choctaw' from SunSeeds, Hollister, Calif.) and planting date (23 Nov. 1994, 14 Dec. 1994, and 17 Jan. 1995). The experiment was arranged in a randomized complete-block design with five replicates. 
Carrot seeds were mechanically seeded into two rows on the bed with $30 \mathrm{~cm}$ between rows, and plants were thinned to a final spacing of $3 \mathrm{~cm}$ for a final plant population of 555,500 plants per ha. Carrots were irrigated with a solid-set sprinkler irrigation system to supplement rainfall and maintain soil moisture tension at $-10 \mathrm{kPa}$, as measured by a tensiometer gauge with the ceramic tip positioned $15 \mathrm{~cm}$ deep in the root zone. Weeds were controlled by periodic hoeing.

Additional $\mathrm{N}$ was applied as sidedressing through the season in variable amounts according to target total-season treatment $\mathrm{N}$ rate (Table 1). Since K leaches in sandy soils, K also was applied uniformly across all $\mathrm{N}$ treatments at 35, 70, and $40 \mathrm{~kg} \cdot \mathrm{ha}^{-1}$ at first, second, and third sidedressings. Fertilizer $\mathrm{N}$ and $\mathrm{K}$ were supplied from mixtures of $\mathrm{NH}_{3} \mathrm{NO}_{3}$ and $\mathrm{KNO}_{3}(\mathrm{KCl}$ for the carrots receiving zero- $\mathrm{N})$. Fertilizer mixtures were applied by hand to the surface of the bed between the two rows of plants and lightly incorporated with a fourtined potato rake. Soil used for this study tested medium in $\mathrm{Mg}$; therefore, $\mathrm{MgSO}_{4}$ was applied at $20 \mathrm{~kg} \cdot \mathrm{ha}^{-1} \mathrm{Mg}$ in the first and second sidedressings.

Weather conditions during Nov. 1994 through May 1995 were very conducive to carrot culture at this site in northern Florida. The lowest temperature recorded during the season was $-7.0^{\circ} \mathrm{C}$ on $9 \mathrm{Feb}$. 1995 ; however, carrots were not damaged by the freezing temperature. Rainfall was sporadic during Winter 1994-95, with total rainfall as follows (in $\mathrm{cm}$ ): November (0.1), December (2.3), January (11.2), February (2.7), March (10.9), April (15.0), and May (8.1). There were only four moderate rainfall events during the season: $8.1 \mathrm{~cm}$ on $15 \mathrm{Jan}$. (just before preplant fertilization and seeding of the second carrot planting), $6.9 \mathrm{~cm}$ on 19 Mar., $7.1 \mathrm{~cm}$ on $6 \mathrm{Apr}$., and $5.7 \mathrm{~cm}$ on 11 May.

Plants from the second planting (14 Dec.) were used for mineral nutrient analyses. Whole seedling shoots were collected from a $30-\mathrm{cm}$ section of row when the plants were $10 \mathrm{~cm}$ tall. Most recently matured whole leaves (blade plus petiole) were collected when the plants were $15 \mathrm{~cm}$ tall and again at harvest. Plant materials were dried in a forced-air oven at 60 ${ }^{\circ} \mathrm{C}$, ground to pass a $0.6-\mathrm{mm}$ screen, digested in $\mathrm{H}_{2} \mathrm{SO}_{4} / \mathrm{H}_{2} \mathrm{O}_{2}$ and analyzed for $\mathrm{N}$ by rapidflow colorimetry (Hanlon et al., 1994; Jones et al., 1991).

Carrots in all plots were harvested when field observation indicated that most roots had attained a length of $15 \mathrm{~cm}$ in the $165-\mathrm{kg} \mathrm{N}$ treatment. The specific growing period, therefore, varied with planting date and cultivar (Table 2). Use of this approach to determine the harvesting date was a compromise among the potentially best harvest dates for carrots with each respective $\mathrm{N}$ fertilization program. Waiting for carrots with very low rates of $\mathrm{N}$ fertilization to gain market size would have taken too long to be practical commercially and would risk excessive sizing of carrots with greater $\mathrm{N}$ rates.

Carrots were loosened from the soil by undercutting below the root tip with a lifting blade, and washed and graded according to U.S. Dept. of Agriculture grade standards (U.S. Dept. of Agriculture, 1965). Roots failing to meet minimum size standards or those misshapen or cracked were classified as cull. Shoots were removed and carrots in each grade category were counted and weighed. Five roots from the U.S. No. 1 class were randomly selected, and the shoots and roots were separated and weighed, placed in a paper bag, and dried in a forced-air oven until constant weight. Dry weights were used to calculate dry-matter content of the roots and root : shoot ratios based on dry matter.

Fifteen roots in each experimental unit were randomly selected from the U.S. No. 1 class for determination of total alcohol-soluble sugars (Dubois et al., 1956) and total carotene concentration from a hexane extract (Umiel and Gabelman, 1971). The roots were cut into pieces and frozen at $-25{ }^{\circ} \mathrm{C}$ while awaiting laboratory preparation and analysis.

Data were analyzed by analysis of variance to determine significance of main effects and presence of interaction among planting date, cultivar, and $\mathrm{N}$ rate. Significant $\mathrm{N}$ rate main effects or simple effects were investigated further with means comparisons or regression analysis.

Table 1. Nitrogen applications and rates for sidedress (SD) fertilization of carrot, Gainesville, Fla., Winter 1994-95.

\begin{tabular}{|c|c|c|c|c|}
\hline \multicolumn{5}{|c|}{$\mathrm{N}$ fertilizer application $\left(\mathrm{kg} \cdot \mathrm{ha}^{-1}\right)^{2}$} \\
\hline At planting & First SD & Second SD & Third SD & Total \\
\hline$\overline{0}$ & 0 & 0 & 0 & $\overline{0}$ \\
\hline 20 & 0 & 25 & 10 & 55 \\
\hline 20 & 20 & 35 & 35 & 110 \\
\hline 20 & 35 & 70 & 40 & 165 \\
\hline 20 & 40 & 80 & 80 & 220 \\
\hline
\end{tabular}

${ }^{\mathrm{z}}$ Sidedressings were made at first expanded true leaf stage (first SD), plants $10 \mathrm{~cm}$ tall (second SD), and plants $15 \mathrm{~cm}$ tall (third SD).

Table 2. Planting and harvesting dates and growing season length for three carrot plantings, Gainesville, Fla., 1994-95.

\begin{tabular}{lllcc}
\hline Planting & & \multicolumn{2}{c}{ Date } & Growing \\
no. & Cultivar & Planting & Harvesting & season (d) \\
\hline 1 & Scarlet Nantes & 23 Nov. & 4 Apr. & 132 \\
& Choctaw & 23 Nov. & 10 Apr. & 138 \\
2 & Scarlet Nantes & 14 Dec. & 17 Apr. & 124 \\
& Choctaw & 14 Dec. & 20 Apr. & 127 \\
3 & Scarlet Nantes & 17 Jan. & 15 May & 118 \\
& Choctaw & 17 Jan. & 20 May & 123 \\
\hline
\end{tabular}

Table 3. Interaction means for the effects of planting date and carrot cultivar on root yield, dry matter, and sugar concentration, and on root : shoot ratio (1994-95).

\begin{tabular}{|c|c|c|c|c|c|c|c|}
\hline \multirow{2}{*}{$\begin{array}{l}\text { Planting } \\
\text { date }\end{array}$} & \multirow[b]{2}{*}{ Cultivar } & \multicolumn{2}{|c|}{$\underline{\text { Root yield }\left(\mathrm{t} \cdot \mathrm{ha}^{-1}\right)}$} & \multirow{2}{*}{$\begin{array}{l}\text { No. mkt. } \\
\text { roots/ha } \\
(\times 1000)\end{array}$} & \multirow{2}{*}{$\begin{array}{c}\text { Dry } \\
\text { matter } \\
\left(\mathrm{g} \cdot \mathrm{kg}^{-1}\right)\end{array}$} & \multirow{2}{*}{$\begin{array}{c}\text { Sugar } \\
\text { concn } \\
\left(\mathrm{mg} \cdot \mathrm{g}^{-1} \mathrm{FW}^{\mathrm{y}}\right)\end{array}$} & \multirow{2}{*}{$\begin{array}{c}\text { Root : shoot } \\
\text { ratio } \\
\end{array}$} \\
\hline & & Large $^{z}$ & Cull $^{z}$ & & & & \\
\hline \multirow[t]{2}{*}{23 Nov. } & Scarlet Nantes & 1.27 & 3.03 & 252 & 108 & 28 & 5.7 \\
\hline & Choctaw & 0.14 & 3.83 & 356 & 110 & 47 & 2.6 \\
\hline \multirow[t]{2}{*}{14 Dec. } & Scarlet Nantes & 0.06 & 4.74 & 238 & 100 & 34 & 3.7 \\
\hline & Choctaw & 0.02 & 6.29 & 250 & 120 & 39 & 2.6 \\
\hline \multirow[t]{2}{*}{17 Jan. } & Scarlet Nantes & 0.38 & 3.50 & 186 & 110 & 37 & 2.5 \\
\hline & Choctaw & 0.40 & 5.93 & 199 & 130 & 39 & 2.0 \\
\hline $\mathrm{LSD}_{0.05}$ & & 0.33 & 0.68 & 25 & 4 & 4 & 0.4 \\
\hline
\end{tabular}

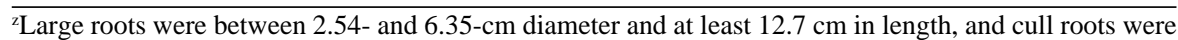
those of unmarketable size or shape.

yFresh weight. 
$\mathrm{y}=0.0029 \mathrm{~N}+0.056$, where $\mathrm{y}$ is yield of large roots in $\mathrm{t} \cdot \mathrm{ha}^{-1}$ and $\mathrm{N}$ is $\mathrm{N}$ rate in $\mathrm{kg} \cdot \mathrm{ha}^{-1}$.

Yield of U.S. No. 1 roots. Production of U.S. No. 1 roots, the most valuable root grade, was affected by interactions between $\mathrm{N}$ rate and both date and cultivar but not by date $x$ cultivar interaction. There were quadratic trends for yields of U.S. No. 1 roots in response to $\mathrm{N}$ fertilization for all three plantings (Table 4). Mean yield for both cultivars was maximized at $27.3 \mathrm{t} \cdot \mathrm{ha}^{-1}$ with $150 \mathrm{~kg} \cdot \mathrm{ha}^{-1} \mathrm{~N}$ for the 23 Nov. planting (Table 5), $21.7 \mathrm{t} \cdot \mathrm{ha}^{-1}$ with $150 \mathrm{~kg} \cdot \mathrm{ha}^{-1} \mathrm{~N}$ for the $14 \mathrm{Dec}$. planting, and $20.4 \mathrm{t} \cdot \mathrm{ha}^{-1}$ with $180 \mathrm{~kg} \cdot \mathrm{ha}^{-1} \mathrm{~N}$ for the $17 \mathrm{Jan}$. planting. As the season progressed (temperature became cooler and days shorter), yield response to a given application of $\mathrm{N}$ decreased.

Yields of U.S. No. 1 carrots increased quadratically with $\mathrm{N}$ application for both 'Scarlet Nantes' and 'Choctaw' (Table 6). However, yield was maximized at $21.0 \mathrm{t} \cdot \mathrm{ha}^{-1}$ with $165 \mathrm{~kg} \cdot \mathrm{ha}^{-1} \mathrm{~N}$ for 'Scarlet Nantes' and at 26.3 t.ha ${ }^{-1}$ with $160 \mathrm{~kg} \cdot \mathrm{ha}^{-1}$ for 'Choctaw' (Table 5).

Total marketable yield. The total number of marketable roots was affected by all twoway interactions (Tables 3, 4, and 6). Yield of marketable roots was greater for 'Choctaw' than for 'Scarlet Nantes' in the first planting (Table 3), but similar for the two cultivars in the second and third. Total number of marketable roots was affected by the interaction of planting date and $\mathrm{N}$ rate. Numbers of marketable roots increased quadratically with $\mathrm{N}$ rate for all three planting dates (Table 4), and were maximized with $155 \mathrm{~kg} \cdot \mathrm{ha}^{-1} \mathrm{~N}$ for the $23 \mathrm{Nov}$. planting, with $150 \mathrm{~kg} \cdot \mathrm{ha}^{-1} \mathrm{~N}$ for the $14 \mathrm{Dec}$. planting, and with $180 \mathrm{~kg} \cdot \mathrm{ha}^{-1} \mathrm{~N}$ for the $17 \mathrm{Jan}$. planting (Table 5). The negligible amounts of marketable-sized carrots with zero $\mathrm{N}$ demonstrated that the soil chosen for this test was low in residual $\mathrm{N}$ and therefore a suitable site for testing carrot $\mathrm{N}$ requirements.

Number of marketable roots also was affected by the interaction of cultivar and $\mathrm{N}$ rate. Although marketable root number increased quadratically with $\mathrm{N}$ rate for both cultivars (Table 6), the maximum responses differed. Root number was maximized at 318,700 roots/ ha with $160 \mathrm{~kg} \cdot \mathrm{ha}^{-1} \mathrm{~N}$ for 'Scarlet Nantes', and at 396,800 roots/ha with $160 \mathrm{~kg} \cdot \mathrm{ha}^{-1} \mathrm{~N}$ for 'Choctaw' (Table 5).

Total marketable yield was affected by the interactions between $\mathrm{N}$ rate and both date and cultivar. In all three plantings, marketable root yield was affected quadratically by $\mathrm{N}$ rate (Table 4). Marketable yield was maximized at $29.1 \mathrm{t} \cdot \mathrm{ha}^{-1}$ with $155 \mathrm{~kg} \cdot \mathrm{ha}^{-1} \mathrm{~N}$ for the $23 \mathrm{Nov}$. planting, $21.9 \mathrm{t} \cdot \mathrm{ha}^{-1}$ with $150 \mathrm{~kg} \cdot \mathrm{ha}^{-1} \mathrm{~N}$ for the 14 Dec. planting, and at $20.5 \mathrm{t} \cdot \mathrm{ha}^{-1}$ with 180 $\mathrm{kg} \cdot \mathrm{ha}^{-1} \mathrm{~N}$ for the $17 \mathrm{Jan}$. planting (Table 5). These responses to $\mathrm{N}$ are in the range previously reported (Hemphill and Jackson, 1982; Hipp, 1978; Sanderson and Ivany, 1997; Tyler, 1986) for various carrot production sites in the United States and Canada. Marketable yields of both 'Scarlet Nantes' and 'Choctaw' increased quadratically with increasing $\mathrm{N}$ rate (Table 6); yield of 'Scarlet Nantes' was maximized at $21.7 \mathrm{t} \cdot \mathrm{ha}^{-1}$ with $165 \mathrm{~kg} \cdot \mathrm{ha}^{-1} \mathrm{~N}$ and at $26.7 \mathrm{t} \cdot \mathrm{ha}^{-1}$ with $160 \mathrm{~kg} \cdot \mathrm{ha}^{-1} \mathrm{~N}$ for 'Choctaw' (Table 5).

Table 4. Interaction means for the effects of planting date and $\mathrm{N}$ rate on carrot root yield, root diameter, root : shoot ratio, and root $\mathrm{N}$ content (1994-95).

\begin{tabular}{|c|c|c|c|c|c|c|c|c|}
\hline \multirow{2}{*}{$\begin{array}{l}\text { Planting } \\
\text { date }\end{array}$} & \multirow{2}{*}{$\begin{array}{c}\mathrm{N} \\
\left(\mathrm{kg} \cdot \mathrm{ha}^{-1}\right)\end{array}$} & \multicolumn{3}{|c|}{ Root yield $\left(\mathrm{t} \cdot \mathrm{ha}^{-1}\right)$} & \multirow{2}{*}{$\begin{array}{l}\text { No. mkt. } \\
\text { roots/ha } \\
(\times 1000)\end{array}$} & \multirow{2}{*}{$\begin{array}{l}\text { Root } \\
\text { diam } \\
(\mathrm{cm})\end{array}$} & \multirow{2}{*}{$\begin{array}{l}\text { Root : shoot } \\
\text { ratio }\end{array}$} & \multirow{2}{*}{$\begin{array}{l}\text { Root N } \\
\left(\mathrm{kg} \cdot \mathrm{ha}^{-1}\right)\end{array}$} \\
\hline & & U.S. No. 1 & Cull & Mkt. & & & & \\
\hline \multirow[t]{6}{*}{23 Nov. } & 0 & 1.4 & 5.5 & 1.4 & 30 & 2.1 & 5.1 & 12.2 \\
\hline & 55 & 19.6 & 3.4 & 20.0 & 323 & 2.8 & 4.8 & 31.5 \\
\hline & 110 & 25.5 & 3.0 & 26.4 & 383 & 2.9 & 3.8 & 44.6 \\
\hline & 165 & 26.3 & 3.0 & 27.4 & 399 & 2.9 & 3.8 & 45.2 \\
\hline & 220 & 24.5 & 2.3 & 25.5 & 384 & 3.0 & 3.5 & 58.0 \\
\hline & Regression & $\mathrm{L}^{* *}, \mathrm{Q}^{* *}$ & $\mathrm{~L}^{* *}, \mathrm{Q}^{*}$ & $\mathrm{~L}^{* *}, \mathrm{Q}^{* *}$ & $\mathrm{~L}^{* *}, \mathrm{Q}^{* *}$ & $\mathrm{~L}^{* *}, \mathrm{Q}^{* *}$ & $\mathrm{~L}^{*}$ & $\mathrm{~L}^{* *}, \mathrm{Q}^{* *}$ \\
\hline \multirow[t]{6}{*}{14 Dec. } & 0 & 0.4 & 4.9 & 0.4 & 10 & 1.7 & 3.4 & 6.4 \\
\hline & 55 & 13.7 & 4.8 & 13.7 & 240 & 2.5 & 3.5 & 26.1 \\
\hline & 110 & 21.3 & 5.7 & 21.4 & 341 & 2.6 & 2.8 & 41.9 \\
\hline & 165 & 19.7 & 5.6 & 19.8 & 320 & 2.6 & 2.9 & 38.8 \\
\hline & 220 & 18.3 & 6.6 & 18.4 & 306 & 2.5 & 2.9 & 39.0 \\
\hline & Regression & $\mathrm{L}^{* *}, \mathrm{Q}^{* *}$ & $\mathrm{~L}^{* *}$ & $\mathrm{~L}^{* *}, \mathrm{Q}^{* *}$ & $\mathrm{~L}^{* *}, \mathrm{Q}^{* *}$ & $\mathrm{~L}^{* *}, \mathrm{Q}^{* *}$ & $\mathrm{~L}^{*}$ & $\mathrm{~L}^{* *}, \mathrm{Q}^{* *}$ \\
\hline \multirow[t]{6}{*}{17 Jan. } & 0 & 0.4 & 4.9 & 0.4 & 5 & 1.8 & 2.5 & 12.2 \\
\hline & 55 & 7.9 & 5.5 & 7.9 & 136 & 2.4 & 2.1 & 37.0 \\
\hline & 110 & 18.5 & 3.8 & 19.1 & 262 & 2.9 & 2.2 & 65.1 \\
\hline & 165 & 19.8 & 4.4 & 20.5 & 282 & 2.8 & 2.3 & 75.0 \\
\hline & 220 & 18.6 & 5.0 & 19.2 & 276 & 3.0 & 2.3 & 86.7 \\
\hline & Regression & $\mathrm{L}^{* *}, \mathrm{Q}^{* *}$ & NS & $\mathrm{L}^{* *}, \mathrm{Q}^{* *}$ & $\mathrm{~L}^{* *}, \mathrm{Q}^{* *}$ & $\mathrm{~L}^{* *}, \mathrm{Q}^{* *}$ & NS & $\mathrm{L}^{* *}$ \\
\hline
\end{tabular}

Ns, ${ }^{,}, * *$ Nonsignificant or significant at $P \leq 0.05$ or 0.01 , respectively.

Table 5. Equation parameters for significant regressions for $\mathrm{N}$ rate at each planting date and each cultivar for several carrot yield and root variables, 1994-95.

\begin{tabular}{|c|c|c|c|c|c|}
\hline \multirow[b]{2}{*}{ Variable } & \multirow{2}{*}{$\begin{array}{c}\text { Unit of } \\
\text { measurement }\end{array}$} & \multicolumn{4}{|c|}{ Equation parameters } \\
\hline & & Intercept & $\mathrm{N}$ rate & $\mathrm{N}$ rate $* \mathrm{~N}$ rate & $\overline{r^{2}}$ \\
\hline \multicolumn{6}{|c|}{ Planted 23 Nov. } \\
\hline U.S. No. 1 & $t \cdot h a^{-1}$ & 2.40 & 0.331 & -0.0011 & 0.76 \\
\hline Cull & $\mathrm{t} \cdot \mathrm{ha}^{-1}$ & 5.25 & -0.029 & 0.000078 & 0.41 \\
\hline Marketable & $\mathrm{t} \cdot \mathrm{ha}^{-1}$ & 2.363 & 0.343 & -0.0011 & 0.79 \\
\hline Marketable & no./ha & 52,840 & 4,870 & -15.6 & 0.73 \\
\hline Root diameter & $\mathrm{cm}$ & 2.194 & 0.0095 & -0.000028 & 0.62 \\
\hline \multicolumn{6}{|c|}{ Planted 14 Dec. } \\
\hline Cull & $\mathrm{t} \cdot \mathrm{ha}^{-1}$ & 4.645 & 0.0079 & & 0.17 \\
\hline Marketable & $t \cdot h a^{-1}$ & 0.7725 & 0.2779 & -0.00092 & 0.85 \\
\hline Marketable & no./ha & 22,220 & 4,390 & -14.39 & 0.87 \\
\hline Root diameter & $\mathrm{cm}$ & 1.786 & 0.0123 & -0.000042 & 0.64 \\
\hline \multicolumn{6}{|c|}{ Planted 17 Jan. } \\
\hline Cull & $\mathrm{t} \cdot \mathrm{ha}^{-1}$ & NS & & & \\
\hline Marketable & $t \cdot h a^{-1}$ & -0.549 & 0.2338 & -0.00065 & 0.65 \\
\hline Marketable & no./ha & 209 & 3,230 & -9.01 & 0.70 \\
\hline Root diameter & $\mathrm{cm}$ & 1.8340 & 0.0127 & -0.000035 & 0.52 \\
\hline \multicolumn{6}{|c|}{ Nantes } \\
\hline U.S. No. 1 & $t \cdot h a^{-1}$ & 1.58 & 0.233 & -0.00070 & 0.78 \\
\hline Cull & $\mathrm{t} \cdot \mathrm{ha}^{-1}$ & 4.85 & -0.0243 & 0.000087 & 0.17 \\
\hline Marketable & $t \cdot h a^{-1}$ & 1.51 & 0.2445 & -0.00074 & 0.76 \\
\hline Marketable & no./ha & 38,680 & 3,490 & -10.88 & 0.82 \\
\hline Root diameter & $\mathrm{cm}$ & 2.16 & 0.0090 & -0.000026 & 0.49 \\
\hline \multicolumn{6}{|c|}{ Choctaw } \\
\hline U.S. No. 1 & $\mathrm{t} \cdot \mathrm{ha}^{-1}$ & 0.251 & 0.3229 & -0.0010 & 0.72 \\
\hline Cull & $\mathrm{t} \cdot \mathrm{ha}^{-1}$ & NS & & & \\
\hline Marketable & $t \cdot h a^{-1}$ & 0.219 & 0.3253 & -0.0010 & 0.72 \\
\hline Marketable & no./ha & 11,500 & 4,830 & -15.15 & 0.71 \\
\hline Root diameter & $\mathrm{cm}$ & 1.72 & 0.0139 & -0.000044 & 0.68 \\
\hline
\end{tabular}

Yield of cull roots. Cull quantity was affected by all three two-way interactions. 'Choctaw' always produced more cull roots than did 'Scarlet Nantes' (Table 3), but the magnitude of the difference was not consistent across the three carrot plantings. Like yield of large roots, few culls were produced and accounted for only $2 \%$ to $4 \%$ of total root production.

Date and $\mathrm{N}$ rate interacted in their effects on cull root quantity, with quadratic $\mathrm{N}$ effects for the first planting, linear effects for the second planting, and no $\mathrm{N}$ fertilization effect for the third planting (Table 4). The equations for the $\mathrm{N}$ rate trends are presented in Table 5. In addition, the cultivar $\times \mathrm{N}$ rate interaction affected cull root yield, with quadratic $\mathrm{N}$ rate effects for 'Scarlet Nantes' and no effect of N fertilization rate on 'Choctaw' (Table 6). The equation for the N rate trend for 'Scarlet Nantes' is presented in Table 5 .

Carrot root length and diameter. Root 
Table 6. Interaction means for the effects of carrot cultivar and $\mathrm{N}$ rate on root yield, root diameter, shoot $\mathrm{N}$, and sugar concentration (1994-95).

\begin{tabular}{|c|c|c|c|c|c|c|c|c|}
\hline \multirow[b]{2}{*}{ Cultivar } & \multirow{2}{*}{$\begin{array}{c}\mathrm{N} \\
\left(\mathrm{kg} \cdot \mathrm{ha}^{-1}\right)\end{array}$} & \multicolumn{3}{|c|}{ Root yield $\left(\mathrm{t} \cdot \mathrm{ha}^{-1}\right)$} & \multirow{2}{*}{$\begin{array}{l}\text { No. mkt. } \\
\text { roots/ha } \\
(\times 1000)\end{array}$} & \multirow{2}{*}{$\begin{array}{l}\text { Root } \\
\text { diam } \\
(\mathrm{cm})\end{array}$} & \multirow{2}{*}{$\begin{array}{l}\text { Shoot N } \\
\left(\mathrm{kg} \cdot \mathrm{ha}^{-1}\right)\end{array}$} & \multirow{2}{*}{$\begin{array}{l}\text { Sugar concn } \\
\left(\mathrm{mg} \cdot \mathrm{g}^{-1} \mathrm{FW}^{\mathrm{z}}\right)\end{array}$} \\
\hline & & U.S. No. 1 & Cull & $\overline{\text { Mkt. }}$ & & & & \\
\hline \multirow[t]{6}{*}{ Scarlet Nantes } & 0 & 1.2 & 4.9 & 1.2 & 27 & 2.1 & 5.9 & 32 \\
\hline & 55 & 12.9 & 3.5 & 13.2 & 222 & 2.7 & 15.3 & 30 \\
\hline & 110 & 19.2 & 3.4 & 19.9 & 285 & 2.9 & 22.9 & 36 \\
\hline & 165 & 19.6 & 3.3 & 20.6 & 302 & 2.8 & 21.4 & 35 \\
\hline & 220 & 19.3 & 3.7 & 20.0 & 289 & 3.0 & 25.1 & 34 \\
\hline & Regression & $\mathrm{L}^{* *}, \mathrm{Q}^{* * *}$ & $\mathrm{~L}^{* *}, \mathrm{Q}^{* *}$ & $\mathrm{~L}^{* *}, \mathrm{Q}^{* *}$ & $\mathrm{~L}^{* *}, \mathrm{Q}^{* *}$ & $\mathrm{~L}^{* *}, \mathrm{Q}^{* *}$ & $\mathrm{~L}^{* *}, \mathrm{Q}^{*}$ & NS \\
\hline \multirow[t]{6}{*}{ Choctaw } & 0 & 0.3 & 5.2 & 0.3 & 2 & 1.7 & 10.6 & 36 \\
\hline & 55 & 14.5 & 5.6 & 14.5 & 245 & 2.4 & 17.5 & 44 \\
\hline & 110 & 24.4 & 4.9 & 24.7 & 373 & 2.8 & 28.7 & 44 \\
\hline & 165 & 24.2 & 5.4 & 24.5 & 365 & 2.7 & 32.7 & 42 \\
\hline & 220 & 21.6 & 5.6 & 22.0 & 355 & 2.7 & 40.3 & 43 \\
\hline & Regression & $\mathrm{L}^{* *}, \mathrm{Q}^{* *}$ & NS & $\mathrm{L}^{* *}, \mathrm{Q}^{* *}$ & $\mathrm{~L}^{* *}, \mathrm{Q}^{* *}$ & $\mathrm{~L}^{* *}, \mathrm{Q}^{* *}$ & $\mathrm{~L}^{* *}$ & $\mathrm{~L}^{* *}, \mathrm{Q}^{*}$ \\
\hline
\end{tabular}

${ }^{2}$ Fresh weight.

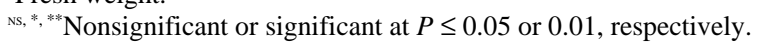

Table 7. Main effect means for carrot cultivar and $\mathrm{N}$ rate on leaf tissue $\mathrm{N}$ concentration for planting No. 2, 14 Dec. 1994.

\begin{tabular}{|c|c|c|c|c|}
\hline \multirow[b]{2}{*}{ Cultivar } & \multirow{2}{*}{$\begin{array}{c}\mathrm{N} \\
\left(\mathrm{kg} \cdot \mathrm{ha}^{-1}\right)\end{array}$} & \multicolumn{3}{|c|}{ Time of sampling ${ }^{2}$} \\
\hline & & Early season & Mid season & Harvest \\
\hline & & \multicolumn{3}{|c|}{$N$ concn $\left(g \cdot \mathrm{kg}^{-1}\right)$} \\
\hline Scarlet Nantes & & 32.1 & 18.2 & 16.2 \\
\hline Choctaw & & 33.4 & 16.2 & 14.4 \\
\hline Significance & & NS & $* *$ & $*$ \\
\hline & 0 & 21.1 & 16.4 & 14.5 \\
\hline & 50 & 32.4 & 13.7 & 12.8 \\
\hline & 110 & 35.3 & 17.6 & 16.1 \\
\hline & 165 & 36.8 & 18.7 & 15.7 \\
\hline & 220 & 38.2 & 19.6 & 17.5 \\
\hline & Regression & $\mathrm{L}^{* *}, \mathrm{Q}^{* *}$ & $\mathrm{~L}^{* *}$ & $\mathrm{~L}^{* *}$ \\
\hline
\end{tabular}

${ }^{2}$ Time of sampling was early season (whole seedlings $10 \mathrm{~cm}$ in height), midseason (most recently matured whole leaves when plants were $15 \mathrm{~cm}$ in height), and at harvest (most-recently matured whole leaves).

Ns,,$* *$ Nonsignificant or significant at $P \leq 0.05$ or 0.01 , respectively.

length was not affected by any treatment interaction, but was greater for 'Choctaw' (20.1 $\mathrm{cm})$, an 'Imperator' type of carrot, than for 'Scarlet Nantes' $(15.2 \mathrm{~cm})$, a 'Nantes' carrot type. Length was greater in the first $(18.1 \mathrm{~cm})$ and the last $(18.0 \mathrm{~cm})$ than in the middle $(16.8$ $\mathrm{cm})$ planting. Length increased quadratically with $\mathrm{N}$ rate, and was greatest at $19.1 \mathrm{~cm}$ with $150 \mathrm{~kg} \cdot \mathrm{ha}^{-1} \mathrm{~N}$. Long carrots are desirable and these results document that greatest root length is obtained with the same N requirement as for greatest yield.

Root diameter was affected by both planting date $\times \mathrm{N}$ rate (Table 4 ) and cultivar $\times \mathrm{N}$ rate interactions (Table 6). Root diameter increased quadratically with $\mathrm{N}$ rate for all three plantings (Table 4). Maximum root diameter occurred with $170 \mathrm{~kg} \cdot \mathrm{ha}^{-1} \mathrm{~N}$ in the $23 \mathrm{Nov}$. planting (3.0 $\mathrm{cm})$, with $145 \mathrm{~kg} \cdot \mathrm{ha}^{-1} \mathrm{~N}$ in the $14 \mathrm{Dec}$. planting $(2.7 \mathrm{~cm})$, and with $180 \mathrm{~kg} \cdot \mathrm{ha}^{-1} \mathrm{~N}$ in the last planting $(3.0 \mathrm{~cm})($ Table 5). Root diameter in both cultivars was affected quadratically by $\mathrm{N}$ fertilization (Table 6), and was maximized at $2.9 \mathrm{~cm}$ with $170 \mathrm{~kg} \cdot \mathrm{ha}^{-1} \mathrm{~N}$ for 'Scarlet Nantes' and at $2.8 \mathrm{~cm}$ with $160 \mathrm{~kg} \cdot \mathrm{ha}^{-1} \mathrm{~N}$ for 'Choctaw' (Table 5).

Root : shoot ratio. Luxuriant shoot growth is often an objective of commercial carrot grower's fertilization programs, although the root is the article of commerce. The growers' objective should be a balance of shoot and root growth that results in maximum marketable carrot production. We evaluated the root : shoot ratio (dry-matter basis) as an indicator of carrot root productivity. Root: shoot ratio was affected by the interactions of planting date with both cultivar (Table 3 ) and $\mathrm{N}$ rate (Table 4). Root : shoot ratio was always greater for 'Scarlet Nantes' than for 'Choctaw' (Table 3), but the difference decreased with planting date.

Root : shoot ratio decreased linearly with $\mathrm{N}$ rate for the 23 Nov. $(y=-0.0083 \mathrm{~N}+5.0)$ and 14 Dec. plantings $(y=-0.0035 \mathrm{~N}+3.47)$, where $\mathrm{y}$ is the value for root : shoot ratio, but was not affected by $\mathrm{N}$ fertilization for the 17 Jan. planting (Table 4). Marketable yield was maximized with $\mathrm{N}$ rates of $150 \mathrm{~kg} \cdot \mathrm{ha}^{-1}$ for the first two planting dates; therefore, increases in shoot growth with $\mathrm{N}$ rate $>150 \mathrm{~kg} \cdot \mathrm{ha}^{-1}$ (decreases in root : shoot ratio) reflected excess $\mathrm{N}$ fertilization and potential reductions in yield and farm profit.

Percent root dry weight was affected by the interaction of planting date and cultivar (Table 3 ). For the earliest planting, percent dry matter was similar for the two cultivars, but values were higher for 'Choctaw' than for 'Scarlet Nantes' for the 14 Dec. and 17 Jan. plantings. Nitrogen fertilization increased percent dry weight $\left[\mathrm{y}\left(\right.\right.$ in $\left.\mathrm{g} \cdot \mathrm{kg}^{-1}\right)=108+0.0035 \mathrm{~N}$, where $\mathrm{N}$ is $\mathrm{N}$ rate in $\mathrm{kg} \cdot \mathrm{ha}^{-1}$ ]. Similar dry-matter contents were observed for carrot in Finland, but dry-matter content was not affected by fertilization (Evers, 1989a).

Plant $N$ content. Shoot and root $\mathrm{N}$ contents were affected by planting date. Shoot $\mathrm{N}$ removal was 21,16 , and $29 \mathrm{~kg} \cdot \mathrm{ha}^{-1}$ for the 23 Nov., 14 Dec., and 17 Jan. planting dates, respectively, whereas root $\mathrm{N}$ removal was 38 , 30 , and $55 \mathrm{~kg} \cdot \mathrm{ha}^{-1}$ and total $\mathrm{N}$ removal was 59 , 46 , and $84 \mathrm{~kg} \cdot \mathrm{ha}^{-1}$.

Cultivar and $\mathrm{N}$ rate interacted in their effects on shoot $\mathrm{N}$ content (Table 6). Shoot N content of 'Scarlet Nantes' increased quadratically, with a maximum at $24 \mathrm{~kg} \cdot \mathrm{ha}^{-1}$ with $195 \mathrm{~kg} \cdot \mathrm{ha}^{-1} \mathrm{~N}$. Shoot N content of 'Choctaw' increased linearly with $\mathrm{N}$ fertilization $(\mathrm{y}=$ $0.149 \mathrm{~N}+11$, where $\mathrm{y}$ is shoot $\mathrm{N}$ content in $\left.\mathrm{kg} \cdot \mathrm{ha}^{-1}\right)$.

Planting date and $\mathrm{N}$ rate interacted in their effects on root $\mathrm{N}$ content (Table 4). Root $\mathrm{N}$ increased quadratically with $\mathrm{N}$ rate for the 23 Nov. and 14 Dec. plantings, maximizing at 57 $\mathrm{kg} \cdot \mathrm{ha}^{-1}$ with $240 \mathrm{~kg} \cdot \mathrm{ha}^{-1} \mathrm{~N}$ (November) and at $42 \mathrm{~kg} \cdot \mathrm{ha}^{-1}$ with $160 \mathrm{~kg} \cdot \mathrm{ha}^{-1} \mathrm{~N}$ (December). For the 17 Jan. planting, root $\mathrm{N}$ content increased linearly $(\mathrm{y}=0.373 \mathrm{~N}+18$, where $\mathrm{y}$ is $\operatorname{root} \mathrm{N}$ content in $\left.\mathrm{kg} \cdot \mathrm{ha}^{-1}\right)$.

Calculations made from data in Tables 4 and 6 show that carrots not fertilized with $\mathrm{N}$ absorbed $\approx 18 \mathrm{~kg} \cdot \mathrm{ha}^{-1} \mathrm{~N}$ (shoots + roots). Soil organic matter concentration was $12 \mathrm{~g} \cdot \mathrm{kg}^{-1}$. Total plant $\mathrm{N}$ removed was $47,67,66$, and 83 $\mathrm{kg} \cdot \mathrm{ha}^{-1} \mathrm{~N}$ with $55,110,165$, and $220 \mathrm{~kg} \cdot \mathrm{ha}^{-1}$ of applied $\mathrm{N}$, respectively. If $\approx 18 \mathrm{~kg} \cdot \mathrm{ha}^{-1}$ of the total absorbed $\mathrm{N}$ were derived from mineralized soil $\mathrm{N}$, then fertilizer $\mathrm{N}$ recovery was $53 \%, 45 \%, 29 \%$, and $30 \%$ for the four treatments, respectively. These recovery values are near the often-cited $\mathrm{N}$ fertilizer recovery value of $50 \%$ (Bock, 1984) for the lower rates of $\mathrm{N}$, but poorer efficiency prevailed with the higher $\mathrm{N}$ rates. In experiments with pepper (Capsicum annuum L.) on the same research farm as the present carrot study, Locascio et al. (1985) measured $\mathrm{N}$ recovery values of $42 \%$ (mulched pepper) and 24\% (unmulched pepper with split applications of $\mathrm{N}$ ). With excessive $\mathrm{N}$ rates, fertilizer use efficiency is low and potential for groundwater pollution greater if the $\mathrm{N}$ is left behind in the soil, subject to leaching. Future research should determine N application schedules, such as more frequent applications of smaller amounts of $\mathrm{N}$ than used in this study, that will increase $\mathrm{N}$ application efficiency.

Carrot leaftissue. Carrots from the second planting were used for gathering tissue- $\mathrm{N}$ data to measure $\mathrm{N}$ deficiency. Whole shoots were used for the early sample and most recently matured whole leaves were used for the second (midseason) and third (harvest) samplings. Tissue $\mathrm{N}$ concentrations for all samplings were affected by cultivar and $\mathrm{N}$ rate only (Table 7). 'Scarlet Nantes' leaves had greater N concentrations than did 'Choctaw' leaves for the midseason and harvest samplings, whereas the differences were nonsignificant for the early sampling. Whole-shoot $\mathrm{N}$ concentration was affected quadratically for the early sampling, maximizing at $38.1 \mathrm{~g} \cdot \mathrm{kg}^{-1}$ with 180 $\mathrm{kg} \cdot \mathrm{ha}^{-1} \mathrm{~N}$. For the midseason and harvest samplings, the whole-leaf $\mathrm{N}$ concentration increased linearly with $\mathrm{N}$ fertilization. Since marketable yield leveled off after $150 \mathrm{~kg} \cdot \mathrm{ha}^{-1}$ $\mathrm{N}$, critical $\mathrm{N}$ concentration profile would be 
36,18 , and $16 \mathrm{~g} \cdot \mathrm{kg}^{-1}$ for the three sampling periods used in this study. These critical values agree with those for $60 \mathrm{~d}$ after planting published by Weir and Cresswell (1993) and by Hochmuth et al. (1991) but are considerably lower than those of Jones et al. (1991) for mature carrot.

Root carotene and sugar concentrations. The concentration of hexane-extractable carotenoids was affected only by planting date and $\mathrm{N}$ fertilization. Cultivar had no significant effects on carotenoid concentration and all interactions were nonsignificant. Carotenoid concentrations were 56,51 , and $42 \mathrm{mg} \cdot \mathrm{kg}^{-1}$ fresh weight $\left(\mathrm{LSD}_{0.05}=6\right)$ for the November, December, and January plantings, respectively. Root carotenoid concentration was influenced quadratically by $\mathrm{N}$ fertilization, maximizing at $55 \mathrm{mg} \cdot \mathrm{kg}^{-1}$ fresh weight with $160 \mathrm{~kg} \cdot \mathrm{ha}^{-1} \mathrm{~N}$. These results agree with those of Freeman and Harris (1951), Mengel (1979), and Venter (1979), who reported that fertilization increased carotene concentration of carrots. Evers (1989b) obtained similar carotene concentrations for carrots in Finland with $150 \mathrm{~kg} \cdot \mathrm{ha}^{-1} \mathrm{~N}$, but this rate of application had no more effect than did $80 \mathrm{~kg} \cdot \mathrm{ha}^{-1} \mathrm{~N}$.

The concentration of total alcohol-soluble sugar in carrot roots was affected by the interactions of planting date $\times$ cultivar and of cultivar $\times \mathrm{N}$ fertilization (Tables 3 and 6). Sugar concentrations of 'Choctaw' roots were greater than those of 'Scarlet Nantes' for the first two plantings (Table 3), but differences between cultivars were nonsignificant for the last planting. Sugar concentration of 'Scarlet Nantes' roots was not affected by $\mathrm{N}$ fertilization (Table 6), whereas that of 'Choctaw' roots increased quadratically, maximizing at 45 $\mathrm{mg} \cdot \mathrm{g}^{-1}$ fresh weight with $140 \mathrm{~kg} \cdot \mathrm{ha}^{-1} \mathrm{~N}$. Nitrogen fertilization did not influence sugar concentration of carrot grown in Finland (Evers, 1989c).

In summary, carrot yield and root quality characteristics were improved with $\mathrm{N}$ fertilization of a sandy soil. The yield responses to $\mathrm{N}$ were quadratic, maximizing in the range of 150 to $180 \mathrm{~kg} \cdot \mathrm{ha}^{-1} \mathrm{~N}$. Carrots grown on sandy soils in Florida therefore responded to $\mathrm{N}$ in a fashion similar to carrots grown on mineral soils in Oregon, Texas, and Canada. Additions of $\mathrm{N}$ in excess of that required for maximum yield only increased shoot growth. Root carotene concentrations were improved by $\mathrm{N}$ fertilization, reaching a maximum with an $\mathrm{N}$ fertilization program similar to that needed for maximum root yield. Sugar concentration in 'Choctaw', but not in 'Scarlet Nantes', was improved by $\mathrm{N}$ fertilization, again maximizing at an $\mathrm{N}$ fertilization rate similar to that needed for maximum yield. Therefore, $\mathrm{N}$ in excess of that needed to maximize yield does not improve carrot quality, and if it remains in the soil, may leach into the groundwater.

\section{Literature Cited}

Adams, F. and C.E. Evans. 1962. A rapid method for measuring lime requirement of red-yellow podzolic soils. Soil Sci. Soc. Amer. Proc. 26:355357

Bock, B.R. 1984. Efficient use of nitrogen in cropping systems, p. 273-294. In: R.D. Hauck (ed.). Nitrogen in crop production. Amer. Soc. Agron., Madison, Wis.

Boswell, V.R. 1963. Commercial growing of carrots. U.S. Dept. Agr. Lflt. No. 353.

Conrow, R.C. 1989. Draft SWIM plan for Lake Apopka. St. Johns River Water Mgt. Dist. Misc. Publ.

Crnko, G.S., A. Ferrer, E.A. Hanlon, C.A. Neal, and J.M. White. 1993. Carrot and sweet corn yields when fertilized according to soil test results. Proc. Fla. State Hort. Soc. 106:199-201.

Dubois, M., K.A. Gilles, J.K. Hamilton, P.A. Rebers, and F. Smith. 1956. Colorimetric method for determination of sugars and related substances. Anal. Chem. 28:350-356.

Evers, A.-M. 1989a. Effects of different fertilization practices on the growth, yield, and dry matter content of carrot. J. Agr. Sci. Finland. 60:135152.

Evers, A.-M. 1989b. Effects of different fertilization practices on the carotene content of carrot. J. Agr. Sci. Finland. 61:7-14.

Evers, A.-M. 1989c. The role of fertilization practices in the yield and quality of carrot (Daucus carota L.). J. Agr. Sci. Finland. 61:329-360.

Florida Agricultural Statistical Services. 1997. Florida agricultural statistics. Vegetable summary. Florida Agr. Stat. Serv., Orlando, Fla.

Follett, R.F. 1991. Seasonal sucrose, dry matter, and cation concentrations of sugarbeet as influenced by variety and $\mathrm{N}$ fertilization. Commun. Soil Sci. Plant Anal. 22:893-906.

Forbes, R.B. 1966. Nitrogen sources for carrots Soil and Crop Sci. Soc. Florida Proc. 26:121124 .

Forbes, R.B. and W.T. Scudder. 1963. Carrot planting date trials in central Florida. Proc. Fla. State Hort. Soc. 76:194-195.

Forbes, R.B. and P.J. Westgate. 1963. Carrot fertilization experiments in central Florida. Soil and Crop Sci. Soc. Florida Proc. 23:99-104.

Freeman, J.A. and G.H. Harris. 1951. The effect of nitrogen, phosphorus, potassium, and chlorine on the carotene content of the carrot. Sci. Agr. 31:207-211.

Hanlon, E., J.G. Gonzales, and J.M. Bartos. 1994. IFAS Extension soil testing laboratory chemical procedures and training manual. Florida Coop. Ext. Serv. Circ. 812.

Hanlon, E.A., G. Kidder, and B.L. McNeal. 1990. Soil, container media, and water testing. Florida Coop. Ext. Serv. Circ. 817.

Hemphill, D.D., Jr. and T.L. Jackson. 1982. Effect of soil acidity and nitrogen on yield and elemental concentration of bush bean, carrot, and lettuce. J. Amer. Soc. Hort. Sci. 107:740-744.

Hipp, B.W. 1978. Response by carrots to nitrogen and assessment of nitrogen status by plant analysis. HortScience 13:43-44.

Hochmuth, G., D. Maynard, C. Vavrina, and E. Hanlon. 1991. Plant tissue analysis and interpretation for vegetable crops in Florida. Florida Coop. Ext. Serv. Spec. Ser. SS-VEC-42.

Jones, J.B., B. Wolf, and H.A. Mills. 1991. Plant analysis handbook. Micro-Macro Publ., Athens, Ga.

Locascio, S.J., J.G.A. Fiskell, D.A. Graetz, and R.D. Hauck. 1985. Nitrogen accumulation by pepper as influenced by mulch and time of fertilizer application. J. Amer. Soc. Hort. Sci. 110:325328.

Locascio, S.J., W.J. Wiltbank, D.D. Gull, and D.N. Maynard. 1984. Fruit and vegetable quality as affected by nitrogen nutrition, p. 617-626. In: R.D. Hauck (ed.). Nitrogen in crop production. Amer. Soc. Agron., Madison, Wis.

Mehlich, A. 1953. Determination of P, Ca, Mg, K, $\mathrm{Na}$, and $\mathrm{NH}_{4}$. North Carolina Soil Testing Div. Mimeo, Raleigh.

Mengel, K. 1979. Influence of exogenous factors on the quality and chemical composition of vegetables. Acta Hort. 93:133-150.

Moore, W.D. 1949. Flooding as a means of destroying the sclerotia of Sclerotinia sclerotiorum. Phytopathology 39:920-927.

Mozafar, A. 1993. Nitrogen fertilizers and the amount of vitamins in plants: A review. J. Plant Nutr. 16:2479-2506.

Rosenfeld, H.J., R.T. Samuelsen, and P.L. Matforsk. 1998. The effect of temperature on sensory quality, chemical composition, and growth of carrots (Daucus carota L.) I. Constant diurnal temperature. J. Hort. Sci. Biotechnol. 73:275-288.

Sanderson, K.R. and J.A. Ivany. 1997. Carrot yield response to nitrogen rate. J. Production Agr. 10:336-339.

Simon, P.W. and C.E. Peterson. 1979. Genetic and environmental components of carrot culinary and nutritive value. Acta Hort. 93:271-278.

Simon, P.W., C.E. Peterson, and R.C. Lindsay. 1980. Genetic and environmental influences on carrot flavor. J. Amer. Soc. Hort. Sci. 105:416420

Simon, P.W., C.E. Peterson, and R.C. Lindsay. 1982. Genotype, soil, and climate effects on sensory and objective components of carrot flavor. J. Amer. Soc. Hort. Sci. 107:644-648.

Southards, C.J. and C.H. Miller. 1962. A greenhouse study on the macroelement nutrition of the carrot. Proc. Amer. Soc. Hort. Sci. 81:335-340.

Strandberg, J.O. 1984. Flooding organic soils to control species of Pythium which attack carrots and other vegetables. Proc. Fla. State Hort. Soc. 97:164-168.

Tyler, K. 1986. Hybrid carrot mineral nutrition. California Coop. Ext. Serv. Veg. Briefs, Issue 256

Umiel, N. and W.H. Gabelman. 1971. Analytical procedures for detecting carotenoids of carrot (Daucus carota L.) roots and tomato (Lycopersicon esculentum) fruits. J. Amer. Soc. Hort. Sci. 96:702-704.

U.S. Department of Agriculture. 1965. United States standards for grades of topped carrots. U.S. Dept. Agr., Washington, D.C.

Venter, F. 1979. Nitrate content in carrots (Daucus carota L.) as influenced by fertilization. Acta Hort. 93:163-172.

Weir, R.G. and G.C. Cresswell. 1993. Plant nutrient disorders. 3. Vegetable crops. Inkata Press, Melbourne, Australia.

Wong, A.D., J.M. Swaider, and J.A. Juvik. 1995. Nitrogen and sulfur fertilization influences aromatic flavor components in shrunken-2 sweet corn kernels. J. Amer. Soc. Hort. Sci. 120:771777. 